\title{
Bio Physicochemical Interactions with Nanomaterials
}

\author{
Merum Sireesha, Veluru Jagadeesh babu* and Seeram Ramakrishna* \\ NUS Centre for Nanofibers and Nanotechnology, Department of Mechanical Engineering, National University of Singapore, Singapore
}

Submission: May 11, 2018; Published: May 22, 2018

*Corresponding author: Veluru Jagadeesh babu, NUS Centre for Nanofibers and Nanotechnology, Department of Mechanical Engineering, National University of Singapore, 2 Engineering Drive 3, Singapore, Email: jbabu2002@gmail.com

Seeram Ramakrishna, NUS Centre for Nanofibers and Nanotechnology, Department of Mechanical Engineering, National University of Singapore, 2 Engineering Drive 3, Singapore, Email: seeram@nus.edu.sg

\section{Mini Review}

Focusing on real time bio physicochemical structural changes induced by nanomaterials (NMs) helps to understand the normal and altered states of cellular and subcellular structures that provides better mechanism in terms of toxicity perspective. The wide usage of engineered NMs was practiced because of its capability to detect and image biomarkers at very low concentration in complex media. Findings provided the strong evidence that NMs not only interact passively but also actively with the cells and regulates the functions [1]. The design of nano-systems for diagnosis and therapeutics should track the cellular responses, such as cell proliferation, apoptosis, adhesion, migration, and cytoskeleton formation. All the physical and chemical characteristics of NMs are inter-linked with the cytotoxicity. For example, cationic NPs is more toxic (by turning gelled phase lipid packing to fluid phase causing leakage of enzymes) when compared with anionic (gelation) and neutral charged (no leakage) NPs of the same size. Usually polymeric nanomaterials with $1.2 \mathrm{~nm}-22 \mathrm{~nm}$ disturb the phospholipid Bilayer by inducing the holes. However, this criteria is changed with surface chemistry on metal nanoparticles, gold nanoparticles conjugates with oligonucleotides about $13 \mathrm{~nm}$ diameter with ordered ligand patterns serves safe cellular uptake. In vivo biocompatibility is determined by bio-physicochemical characteristic of NPs in the field of thernostics. Nanotechnology Characterization Laboratory (NCL) at the National Cancer Institute in Maryland has described that size, surface charge and hydrophobicity are the most influential parameters for biocompatibility (size, shape, surface functionalization, surface charge chemical composition, angle of curvature, porosity, crystallinity, heterogeneity, roughness, ionic strength, $\mathrm{pH}$, temperature, hydrophobicity and/or hydrophilicity). This is concluded after assessing more than 130 different nanoparticles such as polymers, metal oxides, fullerenes, liposomes, dendrimer, gold colloids and quantum dots [2]. Selecting the NMs with best optoelectronic properties is important in imaging, drug delivery and therapeutics. Au and copper NPs evidenced for controlling cancer metastasis and apoptosis respectively. NP-Protein Corona decides the overall biological reactivity and fate of the NPs. Understanding the dynamics of the Nanoparticle-Protein Corona can thus provide useful insights of cytotoxic, inflammatory potential and other important properties of the novel NMs that can be explored for developing safer and value added NMs for future applications. Studies involving the effect of proteins on particles and vice versa is important for understanding potential biological injury, due to such biological injuries causes disease promoting fibrils, exposure of new antigenic epitopes and loss of function such as enzymatic activity. New tools are required for analyzing the catalysts at nano-bio interface to probe dynamic biophysicochemical interactions such as new nanobiosensors to detect the Reactive Oxygen Species by using various redox enzymes aligned on nanoelectrode arrays [3]. For imaging, Scanning Electron Microscope (SEM) and Transmission Electron Microscope (TEM) are good in imaging the electron dense particles like metallic particles but TEM cryomicroscopy is needed for unstained soft biomolecules and intercellular to be visualized in conformational states and better understanding will promote and ignite the exploration of healthy and safe considerations for nanotechnology.

\section{Acknowledgement}

All the authors thank to A*STAR Singapore for the financial support under Individual Research Grant/Advanced Manufacturing \& Engineering domain (AME-IRG) grant.

\section{References}

1. Huang X, Teng X, Chen D, Tang F, He J, et al. (2010) The effect of the shape of mesoporous silica nanoparticles on cellular uptake and cell function. Biomaterials 31: 438-48.

2. McNeil SE (2009) Nanoparticle therapeutics: a personal perspective. Wiley Interdiscip Rev Nanomed Nanobiotechnol 1(3): 264-271.

3. Niemantsverdriet JW (2007) Spectroscopy in Catalysis. 
Your next submission with Juniper Publishers will reach you the below assets

- Quality Editorial service

- Swift Peer Review

- Reprints availability

- E-prints Service

- Manuscript Podcast for convenient understanding

- Global attainment for your research

- Manuscript accessibility in different formats ( Pdf, E-pub, Full Text, Audio)

- Unceasing customer service

Track the below URL for one-step submission https://juniperpublishers.com/online-submission.php 